\title{
THE EFFECTS OF COOPERATIVE LEARNING ACTIVITIES ON IMPROVING STUDENTS' PERCEPTION AND ATTITUDES TOWARDS WRITING SKILLS AT INTERNATIONAL SCHOOL, VIETNAM NATIONAL UNIVERSITY HANOI
}

Tran Thi Lan Huong

VNU International School

\section{ABSTRACT}

With the aim to explore the effectiveness of cooperative learning (CL) activities on improving students' perception and attitudes towards writing skills, the researcher employed two different teaching methods to teach two groups in 10 weeks: CL for experimental group and traditional method for control group. Traditional group learning method only puts students to sit and group without further assistance and careful structure to make group work become teamwork; whereas cooperative learning goes strictly with five elements including positive independence, individual accountability, quality group processing, explicit teaching of small group skills and teaching of social skills. A pre- and post- questionnaire were delivered to students at the beginning and the end of the experiment and the data was analyzed to find out to what extend each method affected students' interest and perception about writing skill. Results from the analysis show that CL is an intriguing and effective way for students to learn writing skills. Learning in groups is generally more interesting and beneficial for their writing performance, especially for those steps like brainstorming ideas or editing essays.

Key words: Cooperative Learning; CL; learning in groups; writing skills; process writing; perception; attitudes....

Received: 10/4/2019; Revised: 27/5/2019; Approved: 31/5/2019

\section{HIỂU QUẢ CỦA HOẠT ĐỘNG HỌC HỘP TÁC ĐỐI VỚI THÁI Độ, NHẬn THỨC CỦA SINH VIỂN KHOA QỨCC TẾ, ĐẠI HỌC QUỐC GIA VỚI KĨ NĂNG VIẾT}

Trần Thị Lan Hương

Khoa Quốc tế - ĐH Quốc gia Hà Nội

\section{TÓM TĂT}

Với mục đích tìm hiểu hiệu quả của việc sử dụng hoạt động học hợp tác, học nhóm để nâng cao nhận thức cũng như thái độ của sinh viên đối với kĩ năng viết, tác giả đã sử dụng hai phương pháp giảng dạy khác nhau cho hai nhóm sinh viên trong 10 tuần. Trước và sau khi tiến hành dạy thử nghiệm, tác giả phát ra hai bảng câu hỏi để phân tích tìm hiểu hiệu quả của từng phương pháp đối với nhận thức và thái độ của sinh viên đối với kĩ năng viết. Kết quả từ phân tích dữ liệu bảng hỏi cho thấy phương pháp học hợp tác là một phương pháp thú vị và có ích cho kĩ năng viết của sinh viên tại Khoa Quốc tế, Đại học Quốc gia Hà Nội. Phương pháp mới không chỉ cải thiện khả năng động não lấy ý, chỉnh sửa bài viết của sinh viên mà còn làm tăng sự tự tin của sinh viên khi viết tiểng Anh. Nghiên cứu đóng vai trò như một gợi ý để cải thiện hoạt động giảng dạy kĩ năng viết tại Khoa cũng như là một nguồn thông tin tham khảo cho các giáo viên tiếng Anh ở các đơn vị khác tham khảo.

Từ khóa: học hợp tác; học nhóm; viết quá trình; thái độ; nhận thức; kĩ năng viết...

Ngày nhận bài: 10/4/2019; Ngày hoàn thiện: 27/5/2019; Ngày duyệt đăng: 31/5/2019

Email: huongtran038@gmail.com

DOI: https://doi.org/10.34238/tnu-jst.2019.06.564 


\section{Introduction}

While teaching English at VNUIS, the researcher found that writing was the hardest skill for students, consequently, most of students were not actively involved in the lessons. Besides, their learning outcomes for this skill were very low. It has been widely believed that there are some sound reasons to take cooperative learning into implementation. Firstly, the most obvious benefit of CL for students falls into academic achievement. Working in groups enables learners to provide each other with information, suggestions, reminders and motivation [1]. They not only achieve better results, develop their thinking and leadership skills but also enjoy their learning with positive views towards other learners, good self-esteem and a sense of belonging to a group. CL strategy was found to be useful for both language education and other aspects such as motivational and communicative activities [2], good relationship with participants and stress overcoming [1]. Moreover, in CL classrooms, lower students learn much from strong partners because when working individually they may get stuck, but collaborating with better students enable them to understand the materials more easily [3].

In the second place, cooperative learning betters students socially and emotionally. CL helps learners to become better communicators and listeners, cooperative members as well as effective leader of a team. Furthermore, CL is also considered an effective remedy for educational problems by not only helping to improve academic results but also encouraging learners to become involved in social and academic settings. It also has good impact on the problem solving ability of children [2]. Children of lower ability who completed their work collaboratively with peers of higher ability had significant improvement in their performance. In addition, learning cooperatively enables learners to communicate with each other, which gives them opportunities to talk together about their work socially and collaboratively [4]. Discussion with peers is also a good way to make writing more meaningful and apparent and helps learners to become able to read their work critically.

A number of research have confirmed the effectiveness of the method as follows: Ahangari and Samadian (2014)'s study [5] about the effect of cooperative learning activities on writing skills of Iranian EFL learners showed that the effect of cooperative learning activities improve the components of writing skills such as content, organization, vocabulary, language use and mechanics. The researchers suggested that writing performance can be improved through smallgroup cooperative interaction among peers in a supportive and stress-reduced environment. Al-besher (2012) [6] carried out an experimental study on the effects of developing the writing skills of ESL students through the cooperative learning strategy for 48 male students studying in the second year in the English language department at $\mathrm{Al}$ Qassim University in Saudi Arabia. The results showed that $\mathrm{CL}$ was beneficial for the pre-writing and revising stages of writing and less effective in the editing stage, which is concerned mainly with structure and mechanics. The attitudes and perceptions of students had also developed after their involvement in CL. In a study by Grami (2010) [7] to evaluate the success of integrating peer feedback in order to develop writing and social skills, the results showed that even though students in both groups did better in the test, students who involved in the peer feedback group outperformed the other group in all aspects of their writing. In Vietnam, Ms Le Tran (2009) [8] did a study to investigate the effectiveness of group-work activities to improve students' writing skills at Tay Bac University. The results showed that 
the application of cooperative learning activities in writing lessons brought about desirable benefits to both teachers and students. They boosted students' interest to learn and to work hard in writing lessons. The findings demonstrated that $\mathrm{CL}$ activities are not biased towards oral communication; it can be some good to any of four language skills.

It was urgent that another teaching method should be found and applied to improve the situation of teaching writing at VNUIS and after a thorough examination, cooperative learning method was chosen to use.

\subsection{Cooperative Learning}

In language learning contexts, CL is defined as within-class grouping of students usually of differing level of foreign language proficiency who learn to work together on specific tasks for projects in such a way that all students in the group benefit from the interactive experience. Students work together to maximize their own and each other's learning. According to Johnson and Johnson (2005) [9], CL is a teaching strategy in which small teams use a variety of learning activities to improve their understanding of a subject, each member is responsible for learning and helping classmates until they all understand and complete the assigned task.

\subsection{Five key elements of Cooperative Learning}

\subsubsection{Positive interdependence}

According to Johnson, Johnson \& Smith (1991) [10], group members understand that they need each other to fulfill the assigned tasks so they will contribute to the learning of group actively. This element is the heart of CL because the nature of cooperative learning is the improvement and maintenance of positive interdependence among team members. Students need to do activities in which they learn to depend on each other as they get help from one another. Instructors may structure positive interdependence by establishing mutual goals to maximize own and each other's productivity, giving joint rewards, for example if all members achieve above the criteria each will receive bonus points, sharing resources with members' different expertise and assigning roles of summarizer, encourager or elaborator. As a result, teamwork will help them learn valuable skills which will benefit them vocationally and socially.

\subsubsection{Face-to-face interaction}

Academic and language learning requires that students have opportunities to understand what they hear and read as well as express themselves in meaningful tasks [11]. Students are engaged in high level thinking skills such as analyzing, explaining, synthesizing and elaborating through cooperative learning. These interactive experiences are extremely valuable for students who are learning English as a second language because they naturally stimulate and develop the students' cognitive, linguistic and social abilities. Thus, students should be taught and reinforced about the way to interact effectively with others. They gradually get to know and trust one another through teambuilding activities. Accepting and supporting one another and resolving conflicts constructively are other useful skills students attain when doing CL tasks. Also, teachers need to model positive interpersonal skills, get students practice the skills as well as encourage them to process the effectiveness of their performance. Focusing on social skill development will increase student's achievement and enhance students' employability, interpersonal relationships and general psychological health [9].

\subsubsection{Individual accountability}

Jolliffe (2007) [13] mentions that each group member is accountable for fulfilling his or her part of the work. Each student needs to develop a sense of personal responsibility to learn and help the rest of the group to learn also. According to Stahl (1994) [14] the reasons why teachers put students in 
cooperative learning groups is all students can achieve higher academic results individually than when they study alone. Consequently, each student must be held individually responsible and accountable for doing his or her own share of the work and for learning what has been aimed to be learned.

\subsubsection{Social skill}

Johnson, Johnson and Holubec (1993) [15] points out those groups cannot function well if students do not have and use the needed social skills such as leadership, decisionmaking, trust-building, communication, and conflict-management skills. For the cooperative learning environment and precisely as academic skills and the learner should utilize the skills they have learnt in completing assigned activities. Stahl (1994) [14] asserts that students are placed in groups and expected to use appropriate social and group skills does not mean students will use automatically use these skills. In order to work as a group, students need to learn to cope with leadership, trust-building, encouragement, compromise and clarifying. Teachers need to describe expected behaviors and attitudes as well as assign students roles to make sure that consciously work on these behaviors in their groups.

\subsubsection{Group processing}

Johnson, Johnson and Holubec (1993) [15] also state that groups need specific time to discuss how well they are achieving goals and maintaining effective working relationship among team members. Teachers need to ensure there is some structure to the group processing. This can be done by assigning such tasks as follows. First, teachers list three members that helped the group be successful. Second, one action that could be added to make the group even more successful tomorrow should be mentioned. Teachers need to monitor the groups and give feedback on how well the group is working together to the groups and the class as a whole.

\section{Research methods}

In order to investigate if cooperative learning influences positively on students' perception and attitudes or not, a quasi-experimental research design was applied in the present study. The data from pre-and postquestionnaire were quantitatively analyzed to find out the answer.

In this study, the researcher chose one class at random to be assigned to the experimental group while another class made up the control group. Each group consists of 18-19 students aged from 19-20. The two groups have common features in terms of number, age, English level and motivation to study. These students also share characteristics with other groups of General English Program at VNU-IS.

During the experiment time, the students in two groups received different treatment.

The control group: The theory of cooperative learning was not taught and applied in this class. 18 students in the control group were taught about different genres of essay and then asked to practise the stages of writing individually in order to deal with the tasks given by the teacher. After the time limit for each stage was over, teachers had some feedbacks on students' products before they continued with the next stage. They were also allowed to ask the teacher any questions or for any further information.

The experimental group: The teacher put 19 students in groups of 3/4 members and made them tackle a task collaboratively. They were also taught about different genres of essays and then asked to work in groups to practise the stages of writing in order to deal with the tasks assigned by the teacher. Students had to finish each stage in the time limit given by the teacher.

Stage 1: Pre-writing - 20 minutes: During this stage, students worked collaboratively to discuss the meaning of the topic, brainstorm and contribute their ideas together, discuss 
appropriate and relevant vocabulary that could be used in the task. They could use dictionaries to check or find more suitable vocabulary. They together organized ideas and produced the outline for the essay.

Stage 2: Drafting and writing stage - 30 minutes: During this stage, each student wrote their own essay without asking other members for help. They were aware that in this stage, they should use the ideas and vocabulary they had prepared in pre-writing stage without paying any attention to grammatical and spelling mistakes.

Stage 3: Revising stage - 20 minutes: The students revised their essays collaboratively. Each student put their essay in front of everyone and starts to read and offer comments. They were instructed that they had to make sure that they used appropriate vocabulary, rearranged any unclear sentences and paragraphs. They should not offer any comments on grammar and spelling mistakes in this stage. After getting feedbacks from peers, each student started writing the second draft.

Stage 4: Editing stage - 20 minutes: Each draft was put in the centre of the group and students edited it collaboratively. They checked for any linguistic mistakes and accuracy including spelling, grammar and punctuation. Correcting errors and mistakes is the main priority in this stage.

\section{Questionnaire}

A questionnaire was distributed to both groups at the beginning and the end of the treatment to investigate students' attitude

Table 1. Comparing pre- and post-responses of 2 groups concerning writing skills in general

\begin{tabular}{|c|c|c|c|c|c|c|c|}
\hline Statements & $\begin{array}{l}\text { about writing skills } \\
\text { n general }\end{array}$ & Mean & $\mathbf{N}$ & SD & $\begin{array}{c}\text { Mean } \\
\text { Difference }\end{array}$ & $\mathbf{t}$ & $\mathbf{p}$ \\
\hline \multirow{2}{*}{ Experiment } & Pre -questionnaire & 31.52 & 19 & 3.11 & \multirow{2}{*}{2.26} & \multirow{2}{*}{2.42} & \multirow{2}{*}{.026} \\
\hline & Post - questionnaire & 33.78 & 19 & 1.47 & & & \\
\hline \multirow{2}{*}{ Control } & Pre -questionnaire & 29.88 & 18 & 1.96 & \multirow{2}{*}{1.2} & \multirow{2}{*}{2.0} & \multirow{2}{*}{.06} \\
\hline & Post-questionnaire & 31.11 & 18 & 1.77 & & & \\
\hline
\end{tabular}

toward general writing and cooperative consisted of 20 statements in which 10 first statements were about general writing and the other 10 statements were about cooperative writing with a 5 point Likert scale (strongly agree, agree, neutral, disagree and strongly disagree). The questionnaire was adapted from Al-Besher (2012) [6]. The Al-Besher's questionnaire was also used to examine the difference in the attitudes and perception of students towards writing skill and cooperative writing before and after the treatment.

\section{Data analysis}

To investigate the effects of different methods on students' attitude towards writing skills and cooperative writing, the results of preand post-questionnaire filled by the both groups were computed using paired samples t-test.

\section{Results and discussion}

\subsection{Analysis of questionnaire about writing skills in general}

With regard to questionnaire about writing skills in general, the results shown in Table 1 indicate that the mean difference was 2.26 , which was significant (paired $t$ test, $t=2.42$, $\mathrm{p}=.026$ ). Meanwhile, the mean difference achieved by students of the control group was 1.2 , which was not significant $(\mathrm{t}=2, \mathrm{p}=.06)$. This means that the responses of students in the experimental group about writing skills in general improved after the treatment while those of students in the control group did not change. learning in writing class. The questionnaire 
Table 2. Comparing the pre-and post-responses within two groups concerning writing skills in general

\begin{tabular}{|c|c|c|c|c|c|}
\hline \multirow{2}{*}{ Number } & \multirow{2}{*}{ Items } & \multicolumn{2}{|c|}{$\begin{array}{c}\text { Experimental } \\
\text { group }\end{array}$} & \multicolumn{2}{|c|}{$\begin{array}{l}\text { Control } \\
\text { group }\end{array}$} \\
\hline & & $\begin{array}{c}\text { Mean } \\
\text { Difference }\end{array}$ & $\mathbf{p}$ & $\begin{array}{c}\text { Mean } \\
\text { Difference }\end{array}$ & $\mathbf{p}$ \\
\hline 1 & The ease of writing skills & .94 & .026 & .38 & .06 \\
\hline 2 & The importance of writing skills & $\underline{\mathbf{1 . 0 5}}$ & .002 & .38 & .09 \\
\hline 3 & The interest of writing skills & $\underline{1.26}$ & .000 & .38 & .09 \\
\hline 4 & Time spent to understand the topic & .78 & .007 & .77 & .004 \\
\hline 5 & Making outlines before writing & .42 & .21 & .72 & .038 \\
\hline 6 & Following the prepared outline when writing & .68 & .008 & .27 & .42 \\
\hline 7 & Correcting grammatical and spelling mistakes when writing & .73 & .012 & .16 & .38 \\
\hline 8 & Revising essays before finishing them & .42 & .11 & .77 & .035 \\
\hline 9 & Editing vocabulary when finishing the essay & $\underline{1.57}$ & .000 & .66 & .035 \\
\hline 10 & Editing grammar when finishing the essay & $\underline{1.73}$ & .000 & .05 & .77 \\
\hline
\end{tabular}

Table 3. Comparing pre- and post-responses of 2 groups concerning cooperative writing activities

\begin{tabular}{llllllll}
\hline $\begin{array}{l}\text { Statements about cooperative } \\
\text { writing }\end{array}$ & Mean & N & SD & Mean Difference & t & p \\
\hline \multirow{2}{*}{ Experiment } & Pre -questionnaire & 27.05 & 19 & 2.77 & \multirow{2}{*}{5.94} & 6.97 & .000 \\
\cline { 2 - 6 } Control & Post - questionnaire & 33.0 & 19 & 1.94 & & \multirow{2}{*}{1.38} & .183 \\
\cline { 2 - 6 } & Pre -questionnaire & 26.44 & 18 & 3.12 & \multirow{2}{*}{1.22} & & \\
\hline
\end{tabular}

Table 2 presents that, in general, after the experiment the attitudes of students in the experimental group toward writing skills improved remarkably in almost all aspects. As shown in Table 2, they had the most improvement in the attitudes toward editing vocabulary and grammar before submitting the essay and the importance and the interest of writing skills with all mean differences above 1.0. Likewise, there was an improvement in the perception of students in the control group about time spent for understanding the topic before writing and editing grammar before submitting with both mean differences being .77. Especially, while the attitudes of the experimental group toward making outlines before writing and revising the essay did not change, the control group changed positively.

\subsection{Analysis of questionnaire about cooperative writing}

With regard to questionnaire about cooperative learning, the results indicated in
Table 3 means that although the responses of students in the experimental group about cooperative writing were not very good at the beginning of the course, then they improved after 10 weeks taking part in cooperative learning classrooms. In the meanwhile, the attitudes and perception of students in the control group toward cooperative learning did not change.

Table 4 presents that, in general, after the treatment students in the experimental group had better attitudes and perception toward all aspects of cooperative writing ( $\mathrm{p}$-value for all items $<0.05)$. They recognized that cooperative writing was a good way for them to learn writing effectively ( $\mathrm{p}$ value for item $1<0.05)$. They also agreed that doing stages of writing with friends was more interesting and beneficial for their writing and wished to have more chances to take part in more cooperative activities ( $\mathrm{p}$ value for item $2,3,4,10<0.05$ ). However, the attitudes of students in the control group toward 
cooperative learning did not change much ( $\mathrm{p}$ value for most items $>0.05$ ). At the beginning of the course, they neither thought that learning in groups was an effective way to learn writing skills nor wished to take part in cooperative learning ( $\mathrm{p}$ value for item $1,10>0.05$ ) and then after the course, they kept their opinion unchanged although they agreed that learning in groups was somehow good for editing essays, improving grammar and being more confidence in speaking and writing ( $\mathrm{p}$ value for item 4,6,7<0.05).

Table 4. Comparing the pre-test and post-responses within two groups concerning cooperative writing

\begin{tabular}{|c|c|c|c|c|c|}
\hline \multirow{2}{*}{ Number } & \multirow{2}{*}{ Items } & \multicolumn{2}{|c|}{$\begin{array}{c}\text { Experimental } \\
\text { group }\end{array}$} & \multicolumn{2}{|l|}{$\begin{array}{c}\text { Control } \\
\text { group }\end{array}$} \\
\hline & & $\begin{array}{c}\text { Mean } \\
\text { Difference }\end{array}$ & $\mathbf{p}$ & $\begin{array}{c}\text { Mean } \\
\text { Difference }\end{array}$ & $\mathbf{p}$ \\
\hline 1 & The effectiveness of cooperative learning & $\underline{1.89}$ & .000 & .33 & .11 \\
\hline 2 & Planning a topic with friends & 1.0 & .005 & .05 & .79 \\
\hline 3 & Revising an essay in groups & 1.1 & .000 & .22 & .21 \\
\hline 4 & Editing an essay in groups & 1.47 & .000 & .61 & .012 \\
\hline 5 & $\begin{array}{l}\text { Improvement in critical thinking thank to } \\
\text { cooperative learning }\end{array}$ & .57 & .023 & .05 & .85 \\
\hline 6 & $\begin{array}{l}\text { Confidence in speaking and writing thank to } \\
\text { cooperative learning }\end{array}$ & 1.15 & .000 & 1.05 & .002 \\
\hline 7 & $\begin{array}{l}\text { Acquiring vocabulary better thank to cooperative } \\
\text { learning }\end{array}$ & 1.15 & .001 & .5 & .04 \\
\hline 8 & Improving grammar thank to cooperative learning & .84 & .014 & .27 & .35 \\
\hline 9 & $\begin{array}{l}\text { Getting higher scores in exams thank to cooperative } \\
\text { learning }\end{array}$ & .89 & .006 & .27 & .096 \\
\hline 10 & $\begin{array}{l}\text { Preference to be involved in more cooperative } \\
\text { learning }\end{array}$ & $\underline{1.94}$ & .000 & .33 & .13 \\
\hline
\end{tabular}

\section{Conclusions and implications}

\subsection{Summary of the findings}

Concerning students' attitudes toward writing skills and cooperative writing, the findings reveal that there were positive changes in their attitudes. At the beginning of the course, students did not think that writing skills was important or interesting, but after 10 week treatment, their opinion changed for the better. At the end of the course, students also had good perception about the stages of writing. For example, they were better aware of the priority of each stage such as checking content of writing during revising stage and checking accuracy during editing stage. With regard to cooperative writing, there was also improvement in students' attitudes after the experiment. Most of students agreed that cooperative learning was a good method to learn writing skill and they preferred to be involved in more cooperative learning in the future.

\subsection{Recommendations}

The recommendations are combining traditional approach and cooperative approach, training students carefully about cooperative learning, assigning groups of different abilities and getting students to write group's diary. Since each approach has its own strengths, teachers should combine flexibly traditional and cooperative approach basing on the specific teaching context to have the most effectiveness.

Besides, when cooperative approach is applied, students need to be carefully trained about cooperative learning because without training cooperative learning will not be beneficial. Students should understand that cooperative learning means encouraging each other sharing responsibility with each other and trusting each other. They should also be 
instructed how to work collaboratively such as how to brainstorm together, how to discuss an essay, how to give comments and get feedbacks.

However, in order to avoid the situation that some students rely too much on other group's member, a group should have a diary in which each member's contribution in each lesson is recorded. This is also a good way to remind students of their responsibility when doing group work.

\subsection{Limitations of the study}

The study is a relatively small scale one with 37 writing papers from two groups and 37 questionnaire respondents. This may be a hindrance which prevents the researcher from getting more precise findings related to cooperative learning. Secondly, the experiment was just carried out with intermediate students, not students of all levels, thus the results cannot be generalized to all EFL students at VNU-IS.

\section{REFERENCES}

[1]. Gillies, R.M. \& Ashman, A.F., Cooperative learning: the social and intellectual outcomes of learning in groups, London: Routledge, 2003.

[2]. Graham, D., Cooperative learning methods and middle school students, Unpublished $\mathrm{PhD}$ thesis, Capella University, 2005.

[3]. Gabriele, A.J., "The influence of achievement goals on the constructive activity of low achievers during collaborative problem solving", British Journal of Educational Psychology, 77 (1), 121-141, 2007.

[4]. Williams, J., Preparing to teach writing: Research, theory and practice, 3rd Ed, Hillsdale, NJ: Lawrence Earlbaum Associates, 2003.

[5]. Ahangari, S. \& Samadian, Z., "The Effect of Cooperative Learning Activities on Writing Skills of Iranian EFL Learners", Linguistics and Literature Studies, 2 (4), 121 - 130, 2014. Doi: 10.13189/1ls.2014.020403.

[6]. Albesher, K.B., Developing the writing skills of ESL students through the collaborative learning strategy, 2012. Retrieved online September, 13th, 2014 from http://www.academia.edu/3822921/Developin
g_Writing_Skills_through_Cognitive_and_Co mpensatory_Learning_Strategies.

[7]. Grami, A., The effects of Intergrating Peer Feedback into University-Level ESL Writing Curriculum: A Comparative Study in a Saudi Context, Doctoral dissertation, Newcastle University, 2010.

[8]. Tran. T. H. L., The effects of cooperative writing activities on improving second-yearstudents at Tay Bac University, Unpublished MA Thesis. Vietnam National University, 2009.

[9]. Johnson, D. W., \& Johnson, R., "New Developments in Social Interdependence Theory", Genetic, Social, \& General Psychology Monographs, 131 (4), pp.285358, 2005.

[10]. Johnson, D. W., Johnson, R. T., \& Smith, K. A., Cooperative Learning: Increasing College Faculty Instructional Productivity. Washington, D.C: The George Washington University, School of Education and Human Development, 1991.

[11]. McGroarty, M., "Cooperative learning and second language acquisition", Cooperative learning: A response to linguistic and cultural diversity, 2, (1), 19-46, 1993.

[12]. Jolliffe. W., Cooperative Learning in the Classroom: Putting it into Practice, Thousand Oaks: Sage Publications, 2007.

[13]. Stahl, R.I., The essential elements of cooperative learning in the classroom, 1994. Retrieved online September 20th 2014 from http:/www.ed.gov/pubs/OR/ConsumerGuides/ cooplear.html.

[14]. Johnson, D., Johnson, R., \& Holubec, E., Cooperation in the classroom, Edina: Interaction Book Company, 1993. 